Jurnal Penyuluhan, Maret 2010 Vol. 6 No.1

\title{
Luas Lahan dan Pemenuhan Kebutuhan Dasar (Kasus Rumah Tangga Petani Miskin di Daerah Dataran Rendah Kabupaten Seluma)
}

\author{
Bahrin $^{1}$, Basita Ginting Sugihen ${ }^{2}$, Djoko Susanto ${ }^{2}$ dan Pang S Asngari ${ }^{2}$ \\ ${ }^{1}$ Dosen Universitas Muhammadiyah Bengkulu \\ ${ }^{2}$ Departemen Sains Komunikasi dan Pengembangan Masyarakat, \\ Fakultas Ekologi Manusia, Institut Pertanian Bogor \\ ${ }^{3}$ Pusat Penelitian Gizi Departemen Kesehatan
}

\begin{abstract}
The mayority of the poor farmers have relativity enough land, approximately $1 \mathrm{Ha}$ per household. Their poverty is considered as relatively poor. There were four factors which make the poor farmers hardly overcome their problems, namely: working pattern which mostly rely on physical potency; low level of adoption of innovation; poverty trap bounding and low competence to manage opportunity and potency. The poor farmers have to be motivated to get involve in learning process. By doing this approachit is hoped that the farmers could change to get bette, more effective dan more productive in land use.
\end{abstract}

Keyword: poor farmers, land, behavior, household's needs

\section{Pendahuluan}

Lahan bagi petani merupakan faktor produksi yang sangat penting. Lahan merupakan sumber pendapatan untuk kelangsungan hidup. Luas pemilikan dan penguasaan lahan merupakan salah satu faktor utama yang menentukan tingkat penda-patan suatu keluarga atau rumah tangga petani. Oleh karena itu, ketiadaan atau sempitnya pemilikan dan penguasaan lahan merupakan awal terjadinya kemiskinan di pedesaan, seperti yang umumnya terjadi pada kemiskinan di pedesaan Jawa.

Sayogyo (1984), mengemukakan bahwa luas pemilikan tanah adalah salah satu faktor penentu untuk peluang berusaha dan bekerja bagi petani. Singarimbun dan Effendi (1989) menambahkan bahwa tingkat pendapatan usahatani diantaranya dipengaruhi oleh luas tanah dan jenis tanaman. Menurut Tan (1991) tingkat pendapatan usahatani ditentukan oleh luas tanah yang dimiliki, yang mencakup luas tanah pemilikan dan luas tanah usahatani.

Pemilikan dan penguasaan merupakan dua hal yang berbeda; pemilikan menunjuk kepada penguasaan formal, sedangkan penguasaan menunjuk kepada aspek efektifitas. Misalnya, jika sebidang tanah disewakan kepada orang lain, maka orang lain itulah yang secara efektif menguasainya (Wiradi, 1984). Berdasarkan pengertian tersebut berarti, seseorang yang memiliki tanah, ia dapat sekaligus sebagai orang yang menguasai tanah tersebut. Tetapi, dapat juga ia memiliki namun tidak menguasai, karena ia sewakan kepada orang lain. Dengan demikian, seseorang yang memiliki dapat sekaligus sebagai penguasa, sebaliknya seseorang yang menguasai sebidang tanah belum tentu ia sebagai pemiliknya. Orang yang memiliki dan sekaligus menguasai tentu akan lebih baik dari orang yang menguasai tapi tidak memiliki. Karena, bagi orang yang memiliki dan sekaligus

\footnotetext{
${ }^{1}$ Korespondensi Penulis:
} 
menguasai, seluruh hasil yang diperoleh hanya untuk dirinya sendiri. Lain halnya dengan orang yang menguasai tapi bukan pemilik (penyewa, bagi hasil), harus membayar sewa atau menyerahkan sebagian hasil kepada pemilik lahan.

Pemilikan dan atau penguasaan lahan yang luas bukanlah merupakan satu-satunya yang menentukan tingkat kesejahteraan suatu keluarga atau rumah tangga. Lahan yang luas jika tidak dikelola atau diusahakan tidak dapat memberikan hasil yang optimal bagi pemiliknya, apalagi jika dibiarkan terlantar atau tidak diusahakan. Sebaliknya, penguasaan yang luas jika bukan sebagai pemilik melainkan penyewa atau bagi hasil juga tidak dapat memperoleh hasil atau keuntungan yang optimal, karena sebagian hasil harus dialokasikan untuk membayar sewa atau diserahkan kepada pemilik lahan, apalagi dengan sewa yang mahal atau sistem bagi hasil yang kurang mencerminkan unsur keadilan antara si penggarap dan pemilik lahan. Oleh karena itu, suatu lahan dapat memberikan hasil yang optimal bagi suatu keluarga atau rumah tangga jika lahan tersebut milik sendiri dan diusahakan sendiri.

Suatu keluarga atau rumah tangga petani yang memiliki dan menguasai lahan yang cukup luas mestinya akan dapat memenuhi berbagai kebutuhan dasar rumah tangganya secara memadai. Tetapi di Provinsi Bengkulu menunjukkan kenyataan yang berbeda. Berbagai hasil penelitian menunjukkan bahwa rata-rata rumah tangga miskin memiliki lahan lebih dari dua hektar. Mengapa mereka miskin? Tulisan ini berusaha mencari jawabannya, dan mencoba menyoroti keterkaitan antara luas pemilikan dan penguasaan lahan dengan pemenuhan kebutuhan dasar rumah tangga petani miskin di daerah dataran rendah Kabupaten Seluma, sedangkan untuk kasus Kabupaten Kepahiang sebagai daerah dataran tinggi disajikan pada artikel tersendiri.

\section{Metode Penelitian}

Penelitian ini didesain sebagai penelitian yang bersifat deskriptif- korelasional dengan menggunakan metode survai. Penentuan lokasi penelitian dilakukan secara bertahap berdasarkan pembagian zona wilayah, mengacu kepada Peraturan Daerah Nomor 65 Tahun 2006. Wilayah Provinsi Bengkulu dapat dibagi atas dua zona, yaitu: Zona 1 adalah zona dataran rendah yang membentang di sepanjang pantai, dari Kabupaten Kaur sampai ke Kabupaten Mukomuko, yang meliputi kabupaten: Kaur, Bengkulu Selatan, Seluma, Kota Bengkulu, Bengkulu Utara dan Mukomuko; dan Zona 2 adalah zona dataran tinggi, dengan kemiringan di atas $15 \%$, yang meliputi kabupaten: Kepahiang, Rejang Lebong dan Lebong.

Penelitian dilakukan di Kabupaten Seluma sebagai kabupaten yang mewakili daerah dataran rendah. Pemilihan kabupaten sebagai lokasi penelitian dilakukan secara acak melalui undian. Sebelum dilakukan pemilihan, terlebih dahulu dikeluarkan Kota Bengkulu dengan pertimbangan bahwa fokus penelitian ini adalah rumah tangga petani miskin, sedangkan di Kota Bengkulu mayoritas penduduk miskin bukan petani.

Populasi berjumlah 35.423 rumah tangga miskin. Besar sampel ditentukan dengan menggunakan rumus Slovin dengan batas error 6,5\%. Besarnya alokasi sampel pada masing-masing kabupaten ditentukan dengan mempertimbangkan porsi jumlah penduduk miskin serta kepentingan pengolahan data. Di Kabupaten Seluma diambil dua kecamatan dan masing-masing kecamatan diambil dua desa sebagai sampel tempat pelaksanaan penelitian. Di tiap desa diambil 35 rumah tangga, jumlah sampel 140 rumah tangga. Pengambilan sampel rumah tangga petani miskin dilakukan secara acak.

Data primer diperoleh dengan mendatangi dan melakukan wawancara terhadap responden dengan berpedoman pada kuesioner. Kuesioner yang digunakan terlebih dahulu sudah diuji tingkat validitas dan reliabilitasnya. Data primer juga dilengkapi dengan 
wawancara mendalam, baik terhadap responden maupun terhadap pemimpin formal dan informal setempat.

Analisis data dilakukan secara deskriptif dan kuantitatif. Analisis deskriptif ditujukan untuk mendeskripsikan data yang bersifat deskriptif. Analisis kuantitatif dilakukan untuk uji hipotesisi (hubungan antar peubah) dengan menggunakan uji statistika. Analisis statistika yang dilakukan meliputi: (1) analisis statistika deskriptif, (2) analisis korelasi, dan (3) analisis regresi berganda.

\section{Hasil Dan Pembahasan}

\section{Luas Pemilikan dan Penguasaan Lahan}

Rumah tangga petani miskin di Kabupaten Seluma umumnya memiliki dan atau menguasai lahan yang cukup luas. Setiap rumah tangga rata-rata memiliki atau menguasai lahan daratan 0,986 hektar, lahan sawah 0,621 hektar dan lahan pekarangan 0,136 hektar. Keadaan tingkat pemilikan dan penguasaan lahan rumah tangga petani miskin di lokasi penelitian disajikan pada Tabel1.

Sebagian besar (72,15 persen) rumah tangga petani miskin memiliki lahan pekarangan dengan status kepemilikan; bersertifikat sebanyak (37,86 persen) dan hak milik adat sebanyak (34,29 persen). Luas lahan pekarangan yang dimiliki sebagian besar (83,87 persen) berkisar antara $100-2500 \mathrm{~m}^{2}$. Di antara 140 rumah tangga petani miskin terdapat (27,86 persen) yang menempati lahan pekarangan dengan status menumpang. Mereka mendirikan rumah/tempat tinggal dengan menumpang pada lahan pekarangan milik kerabat. Umumnya masih ada pertalian hubungan darah, misalnya anak, saudara atau keponakan. Jangka waktunya, ada yang dibatasi dan ada yang tidak. Namun ada pula yang langsung menjadi hak milik, baik melalui pemberian maupun dibeli dengan cara mencicil.

Lahan daratan yang biasanya digunakan untuk menanam padi ladang, palawija, atau tanaman perkebunan, sebagian besar $(62,14$ persen) merupakan milik sendiri, dengan status kepemilikan: bersertifikat sebanyak (12,14 persen) dan hak milik adat sebanyak (50 persen). Luas lahan daratan yang dimiliki atau dikuasai sebagian besar (52,14 persen) berkisar antara 0,69 sampai dengan 1,56 hektar. Di antara 140 rumah tangga petani miskin terdapat (27,87 persen) menguasai lahan daratan dengan cara menumpang dan (10 persen) dengan cara menyewa atau kontrak. Rumah tangga yang berstatus menumpang, umumnya kerabat dekat dan kebanyakan adalah hubungan antara anak dan orangtua, sedangkan yang menyewa atau kontrak umumnya jarang dari kerabat dekat seperti yang menumpang. Kalaupun mempunyai hubungan garis keturunan, tapi sudah jauh atau bahkan tidak mempunyai hubungan kerabat sama-sekali.

Rumah tangga petani miskin di Seluma umumnya memiliki dan atau menguasai lahan sawah, sebagian besar (55 persen) merupakan lahan milik sendiri, dengan status kepemilikan: bersertifikat sebanyak 12,86 persen dan hak milik adat sebanyak 42,14 persen. Luas lahan sawah yang dimiliki atau dikuasai sebagian besar 66,43 persen berkisar antara 0,20 sampai dengan 0,64 hektar. Di antara 140 rumah tangga petani miskin terdapat 26,43 persen yang menguasai lahan sawah dengan cara menumpang dan 18,57 persen dengan cara menyewa atau kontrak. 
Tabel 1. Pemilikan dan Penguasaan Lahan Rumah Tangga Petani Miskin

\begin{tabular}{|c|c|}
\hline Jenis lahan, Luas dan Status Kepemilikan & Persentase \\
\hline \multicolumn{2}{|l|}{ Lahan Pekarangan : } \\
\hline - Luas : $<2500 \mathrm{~m}^{2}$ & 83,87 \\
\hline $2500-5000 \mathrm{~m}^{2}$ & 9,29 \\
\hline $5001-7500 \mathrm{~m}^{2}$ & 2,86 \\
\hline $7501-10.000 \mathrm{~m}^{2}$ & 4,29 \\
\hline \multicolumn{2}{|l|}{ - Status Kepemilikan: } \\
\hline Sertifikat & 37,86 \\
\hline Hak milik adat & 34,29 \\
\hline Menumpang & 27,86 \\
\hline \multicolumn{2}{|l|}{ Lahan Daratan: } \\
\hline $0,25-0,68 \mathrm{Ha}$ & 25,00 \\
\hline $0,69-1,12 \mathrm{Ha}$ & 25,71 \\
\hline $1,13-1,56 \mathrm{Ha}$ & 26,43 \\
\hline $1,57-2,00 \mathrm{Ha}$ & 22,86 \\
\hline \multicolumn{2}{|l|}{ - Status Kepemilikan: } \\
\hline Sertifikat & 12,14 \\
\hline Hak milik adat & 50,00 \\
\hline Sewa/kontrak & 10,00 \\
\hline Menumpang & 27,87 \\
\hline \multicolumn{2}{|l|}{ Lahan Sawah: } \\
\hline $0,20-0,64 \mathrm{Ha}$ & 66,43 \\
\hline $0,65-1,09 \mathrm{Ha}$ & 25,00 \\
\hline $1,10-1,54 \mathrm{Ha}$ & 2,14 \\
\hline $1,55-2,00 \mathrm{Ha}$ & 6,43 \\
\hline \multicolumn{2}{|l|}{ - Status Kepemilikan: } \\
\hline Sertifikat & 12,86 \\
\hline Hak milik adat & 42,14 \\
\hline Sewa/kontrak & 18,57 \\
\hline Menumpang & 26,43 \\
\hline
\end{tabular}

Berdasarkan paparan di atas memperlihatkan bahwa lebih dari 50 persen rumah tangga petani miskin menguasai lahan milik sendiri, baik pekarangan, lahan daratan maupun lahan sawah. Hal itu menunjukkan bahwa rumah tangga petani miskin di daerah ini pada dasarnya mempunyai potensi sumberdaya ekonomi (lahan) yang cukup memadai untuk memperbaiki kondisi kehidupan keluarga atau rumah tangganya. Jika lahan tersebut dapat dikelola dan dimanfaatkan dengan baik, tentu akan dapat memenuhi kebutuhan dasar rumah tangga mereka atau bahkan dapat melepaskan mereka dari lilitan kemiskinan.

\section{Pemenuhan Kebutuhan Dasar Rumah tangga}

Konsep kebutuhan rumah tangga yang dipakai dalam penelitian ini adalah konsep pemenuhan hak-hak dasar. Oleh karena itu pemenuhan kebutuhan rumah tangga adalah meliputi pemenuhan kebutuhan-kebutuhan: pangan, perumahan, air bersih, pendidikan, kesehatan, lapangan pekerjaan dan kesempatan berusaha, dan kebutuhan akan rasa aman. Keadaan tingkat pemenuhan kebutuhan rumah tangga petani miskin di lokasi penelitian disajikan pada Tabel 2. 
Tabel 2. Pemenuhan Kebutuhan Rumah Tangga Petani Miskin

\begin{tabular}{llc}
\hline Jenis Kebutuhan & Kategori Pemenuhan & Persentase \\
\hline Pangan & Baik & 20,71 \\
& Cukup & 48,57 \\
Perumahan & Kurang & 30,71 \\
& Layak & 2,86 \\
& Cukup Layak & 44,29 \\
& Kurang layak & 42,14 \\
Air bersih & Sangat tidak layak & 10,71 \\
& Baik & 15,71 \\
Akses Layanan Pendidikan Dasar Anggota & Tinggi & 84,29 \\
RT & Sedang & 73,57 \\
& Kurang & 21,43 \\
& Sangat kurang & 4,29 \\
Akses Layanan Kesehatan & Baik & 0,71 \\
& Cukup & 4,29 \\
& Kurang & 71,43 \\
Akses Lapangan Pekerjaan & Sangat kurang & 19,29 \\
& Baik & 5,00 \\
Kebutuhan akan Rasa Aman & Kurang & 8,57 \\
& Sangat kurang & 85,00 \\
& Sangat aman & 6,43 \\
& Aman & 25,71 \\
& & 74,29 \\
\hline
\end{tabular}

Sebagian besar $(69,28$ persen) rumah tangga petani miskin di Seluma mampu memenuhi kebutuhan pangan keluarganya pada kategori cukup dan baik. Umumnya mereka makan nasi tiga kali sehari secara berkesinambungan dengan porsi cukup, dan minimal tiga kali seminggu makan ayam, telur atau ikan. Diantara 140 rumah tangga petani miskin terdapat 30,71 persen tingkat pemenuhan kebutuhan pangannya pada kategori kurang. Mereka umumnya makan nasi antara satu sampai dua kali sehari dengan porsi yang kurang terutama pada saat paceklik menjelang musim panen.

Kondisi rumah petani miskin sebagian besar (52,85 persen) kurang layak dan sangat tidak layak, terutama dilihat dari segi atap, dinding, lantai dan luas lantai. Dilihat dari jenis dinding terluas, sebagian besar (61,43 persen) adalah batu bata merah yang tidak diplaster, dan bahkan terdapat (10 persen) dinding rumah atau pondok untuk tempat tinggalnya terbuat dari bambu (pelupuh). Atap rumah, sebagian besar (79,29 persen) adalah seng, namun kondisinya sudah banyak yang bocor dan sebagian merupakan seng bekas. Sebagian besar $(55,71$ persen) rumah petani miskin berlantai semen, namun ada 35 persen yang berlantai tanah atau bambu. Dilihat dari luas lantai, sebagian besar (73,57 persen) berkisar antara $16-37 \mathrm{~m}^{2}$, dan jika dihubungkan dengan standar luas lantai ideal per jiwa seluas $8 \mathrm{~m}^{2}$, maka sebagian besar rumah/tempat tinggal petani miskin di sini tidak memenuhi standar tersebut. Sebaran jumlah petani miskin dilihat dari kondisi rumah disajikan pada Tabel 3 .

Tingkat pemenuhan kebutuhan air bersih sebagian besar $(84,29$ persen) pada kategori cukup. Sumber air untuk air minum, memasak makanan maupun untuk mandi dan mencuci umumnya digunakan air sumur atau mata air. Air sumur yang digunakan umumnya tidak ditutup, tetapi dibiarkan terbuka dan pengambilan air kebanyakan dilakukan dengan menggunakan timba yang memakai derek. Pemenuhan kebutuhan air bersih umumnya cukup baik. 
Tabel 3. Jumlah Ptani Miskin menurut Kondisi Rumah di Kabupaten Seluma

\begin{tabular}{llc}
\hline Kondisi Rumah & Kategori & Persentase \\
\hline Jenis Dinding Terluas & Tembok/beton & 16,43 \\
& Papan dilicinkan & 11,43 \\
& Bata merah & 61,43 \\
& Bambu & 10,71 \\
Jenis Atap Terluas & Genteng beton/tanah & 0 \\
& Sirap/asbes & 18,57 \\
& Seng & 79,29 \\
Jenis Lantai Terluas & Ijuk/daun rumbia & 2,14 \\
& Marmer/keramik & 0 \\
& Semen & 55,71 \\
& Papan & 9,29 \\
Luas Lantai & Bambu atau tanah & 35,00 \\
& $49-60 \mathrm{~m}^{2}$ & 6,43 \\
& $38-48 \mathrm{~m}^{2}$ & 20,00 \\
& $27-37 \mathrm{~m}^{2}$ & 46,43 \\
& $16-26 \mathrm{~m}^{2}$ & 27,14 \\
\hline
\end{tabular}

Pemenuhan hak atas layanan pendidikan dasar bagi anggota rumah tangga sebagian besar (73,57 persen) tergolong tinggi. Artinya sekitar (73,57 persen) anggota rumah tangga petani miskin di daerah ini mampu menikmati layanan pendidikan dasar. Dilihat dari pendidikan tertinggi anggota keluarga sebagian besar $(51,43)$ tamat sekolah dasar (SD). Angka partisipasi pendidikan dasar anggota rumah tangga petani miskin sebagian besar ( 75,71 persen) berkisar antara (76 - 100 persen), dan angka drop-out pendidikan dasar sebagian besar (80,71 persen) kurang dari 26 persen. Kondisi tingkat pemenuhan hak memperoleh layanan pendidikan rumah tangga petani miskin di lokasi penelitian disajikan pada Tabel 4.

Tabel 4. Pemenuhan Hak Memperoleh Pendidikan Bagi Anggota Rumah Tangga Petani Miskin

\begin{tabular}{clc}
\hline \multicolumn{1}{c}{ Parameter } & Kategori & Persentase \\
\hline Pendidikan Tertinggi Anggota Rmt & Perguruan Tinggi & 0,71 \\
& SLTA & 26,43 \\
& SLTP & 15,71 \\
& SD & 51,43 \\
& Tidak Tamat SD & 6,43 \\
Angka Partisipasi Pendidikan Dasar & $76-100 \%$ & 75,71 \\
& $51-75 \%$ & 18,57 \\
& $26-50 \%$ & 5,00 \\
Angka Drop Out Pendidikan Dasar & $<26 \%$ & 0,71 \\
& $<26 \%$ & 80,71 \\
& $26-50 \%$ & 12,14 \\
& $51-75 \%$ & 5,71 \\
& $>75 \%$ & 0,71 \\
\hline
\end{tabular}

Akses rumah tangga petani miskin terhadap layanan kesehatan sebagian besar $(71,43 \%)$ pada kategori cukup. Artinya bahwa sebagian besar rumah tangga miskin di daerah ini mampu memperoleh layanan kesehatan bagi anggota rumah tangganya. Dilihat dari tingkat kematian balita tergolong rendah. Sebagian besar (97,86 persen) rumah tangga 
petani miskin di lokasi penelitian berobat di Puskesmas, bila ada anggota keluarganya yang sakit. Tingkat kematian balita dan tempat berobat bagi anggota rumah tangga petani miskin di sajikan pada Tabel 5.

Tabel 5. Tingkat Kematian Balita dan Tempat Berobat bagi Anggota Rumah Tangga Petani Miskin

\begin{tabular}{llc}
\hline Parameter & Kategori & Persentase \\
\hline Angka Kematian Balita & Tidak ada & 76,43 \\
& Satu Orang & 12,14 \\
& Dua Orang & 7,14 \\
& $>$ Dua Orang & 4,29 \\
\multirow{2}{*}{ Tempat Berobat } & Rumah Sakit & 2,14 \\
& Puskesmas & 97,86 \\
\hline
\end{tabular}

Akses rumah tangga petani miskin terhadap lapangan pekerjaan dan kesempatan berusaha di luar usahatani yang dilakukannya, sebagian besar (91,43 persen) kurang dan sangat kurang. Hal ini diduga terkait dengan rendahnya tingkat akses rumah tangga miskin terhadap informasi, akses pasar dan akses terhadap sumber modal. Pola kerja dan usaha yang dilakukan lebih mengandalkan kekuatan otot dan mengikuti pola yang sudah bersifat turun-temurun. Informasi untuk bekerja sebagai buruh tani harian biasanya diperoleh dari mulut ke mulut dan umumnya terbatas di lingkungan tempat tinggal (desa).

Kondisi keamanan yang dirasakan rumah tangga petani miskin, baik di sekitar tempat tinggal maupun keamanan terhadap tindak pencurian terhadap hasil usahatani yang dilakukan umumnya relatif aman. Hal ini menunjukkan bahwa dari aspek keamanan cukup kondusif bagi setiap warga untuk melaksanakan berbagai aktivitas bagi kelangsungan hidupnya.

Berdasarkan paparan tentang kondisi luas pemilikan dan penguasaan lahan dan tingkat pemenuhan kebutuhan dasar rumah tangga petani miskin di Kabupaten Seluma, menunjukan bahwa kemiskinan yang terjadi di daerah ini lebih kepada kemiskinan relatif, walaupun demikian ada sebagian kecil yang cenderung pada kemiskinan absolut. Rumah tangga petani miskin umumnya memiliki dan menguasai lahan yang cukup luas serta mampu memenuhi berbagai kebutuhan dasar minimalnya. Mengacu kepada pendapat Sen (1982), orang miskin bukan karena tidak memiliki sesuatu, melainkan karena tidak dapat melakukan sesuatu untuk memperbaiki kondisi kehidupannya.

Hasil analisis korelasi Spearman antara luas pemilikan dan penguasaan lahan dengan pendapatan rumah tangga menunjukkan tidak terdapat hubungan yang nyata dengan koefisien korelasi sebesar 0,0825. Hal ini berarti bahwa pemilikan dan penguasaan lahan yang luas tidak secara otomatis tingkat pendapatannya juga tinggi, atau sebaliknya. Walaupun secara teoritis, petani yang memiliki dan menguasai lahan yang luas akan mempunyai pendapatan yang lebih tinggi dibandingkan petani yang berlahan sempit, karena luas pemilikan dan penguasaan lahan merupakan faktor utama yang mempengaruhi tingkat pendapatan petani, seperti dikemukakan oleh Sajogyo (1984), Tan (1991) dan Singarimbun dan Effendi (1989). Tetapi faktanya menunjukkan bahwa walaupun mereka memiliki dan menguasai lahan yang cukup luas, namun mereka masih termasuk miskin.

Fakta tersebut menunjukkan bahwa produktivitas lahan yang dimiliki atau dikuasai rendah. Ada beberapa faktor penyebab, mengapa mereka miskin pada hal memiliki atau menguasai lahan yang cukup luas? Pertama; lahan luas yang mereka miliki belum dikelola dan dimanfaatkan secara optimal (intensif), sehingga tingkat produktivitasnya rendah. Usahatani yang dilakukan, khususnya padi masih bersifat subsisten. Lahan sawah irigasi lebih banyak ditanami sekali setahun. Adopsi inovasi rendah. Pola kerja dan usaha 
mengikuti pola yang sudah bersifat turun-temurun. Komoditas usahatani yang ditanam bukan didasarkan atas permintaan pasar, tetapi lebih pada kebiasaan.

Kedua: harga produk usahatani, khususnya sektor tanaman pangan tidak sebanding dengan harga produk industri yang sudah menjadi kebutuhan rumah tangga petani, seperti; minyak goreng, minyak tanah, susu, pakaian, sabun mandi, pasta gigi, biaya sekolah (alat tulis, buku dan pakaian seragam) dan sebagainya. Minyak goreng, misalnya; harga di pedesaan mencapai Rp 10.000,- per kg, jika dibandingkan dengan harga beras saat musim panen berkisar antara Rp 2000,- sampai Rp 3000,- per kg. Untuk membeli $1 \mathrm{~kg}$ minyak goreng berarti mereka harus menjual $3-5 \mathrm{~kg}$ beras. Apalagi jika komoditas yang ditanam selain padi bukan didasarkan atas permintaan pasar, harganya dapat berfluktuasi.

Ketiga: jebakan kemiskinan seringkali membuat kemampuan sumberdaya keluarga terpecah, tidak dapat dialokasikan secara penuh pada upaya pemanfaatan lahan milik sendiri, melainkan harus dibagi untuk menjadi buruhtani harian guna memenuhi kebutuhan pangan keluarga. Semakin besar tingkat kekurangan pangan keluarga yang harus ditanggung semakin banyak alokasi sumberdaya (tenaga kerja) yang harus digunakan untuk menjadi buruh harian, dan itu berarti semakin sedikit peluang untuk mengelola dan mengurus lahan miliknya sendiri. Akibatnya lahan milik sendiri tidak tergarap atau tidak terkelola dengan baik, sehingga produktivitasnya rendah dan tingkat pendapatan dari usahatani milik sendiri juga rendah. Dengan demikian tingkat ketergantungannya untuk menjadi buruhtani harian semakin besar dan kemampuan untuk mengelola dan memanfaatkan lahan milik sendiri semakin kecil atau terbatas.

Rendahnya tingkat pendidikan (formal dan non formal) dan akses terhadap informasi terutama yang terkait dengan usahatani yang dilakukan menyebabkan tidak terjadinya proses belajar yang efektif pada petani miskin terutama dalam bekerja dan berusaha, seiring dengan terjadinya perubahan yang sangat cepat pada berbagai aspek kehidupan, sehingga perilakunya menjadi kurang efektif dan kurang produktif. Kegagalan atau rendahnya tingkat produksi dan pendapatan yang dicapai tidak dijadikan bahan pelajaran untuk melakukan perbaikan-perbaikan atau mencari alternatif-alternatif lain yang dapat dilakukan. Terjadinya perubahan lingkungan strategis mengharuskan terjadinya perubahan perilaku manusianya. Sebagai contoh; terjadinya penurunan tingkat kesuburan tanah, mengharuskan petani untuk melakukan tindakan untuk mengembalikannya melalui pemupukan, begitu juga dengan komoditas tanaman yang ditanam hendaknya disesuaikan dengan permintaan pasar bukan didasarkan atas kebiasaan. Rumah tangga petani miskin yang cenderung mangandalkan usahatani tanaman pangan, tingkat kemiskinannya lebih parah dibandingkan dengan petani yang disamping usahatani tanaman pangan juga mengusahakan tanaman perkebunan.

Masyarakat, khususnya petani harus disadarkan agar mereka mau dan mampu untuk belajar secara terus-menerus agar dapat merespon dan berperilaku secara tepat dalam menghadapi perubahan dalam berbagai aspek kehidupan yang sangat cepat. Dengan cara demikian, mereka akan dapat menemukan dan memanfaatkan peluang dan potensi yang dimiliki bagi kelangsungan hidup keluarga atau rumah tangganya.

Para petani miskin harus berubah dari pola yang bersifat subsisten dan berpikir jangka pendek ke pola pikir dan pola tindak yang bersifat perspektif jangka panjang. Makna tanah (lahan) yang sudah terinternalisasi dalam budaya dan sudah dipahami sebagai sesuatu yang penting dan menjadi simbul status sosial dalam masyarakat, tidak sekedar dilihat dari segi kepemilikan belaka, tetapi harus diarahkan pada bagaimana mengelola dan memanfaatkan lahan tersebut secara optimal agar dapat memberikan manfaat yang sebesar-besarnya bagi peningkatan kesejahteraan.

Persoalannya, bagaimana mengubah pola pikir dan pola budaya yang sudah terinternalisasi dalam benak (kepala) setiap orang atau warga masyarakat khususnya warga 
miskin? Dalam kaitan ini, maka pendidikan non formal menjadi sangat penting untuk dilaksanakan secara sungguh-sungguh, terencana dan ditangani secara profesional. Tanpa terjadinya proses belajar dalam masyarakat, sulit diharapkan tercapainya peningkatan kesejahteraan dalam masyarakat tersebut secara mandiri dan berkesinam-bungan.

\section{Kesimpulan}

Mayoritas rumah tangga petani miskin di lokasi penelitian memiliki dan atau menguasai lahan yang cukup luas, sebagian besar lahan pekarangan, lahan daratan dan lahan sawah yang dikuasai adalah milik sendiri. Tingkat pemenuhan kebutuhan dasar, khususnya pangan, air bersih, layanan kesehatan, layanan pendidikan dasar bagi anggota keluarga, dan kebutuhan akan rasa aman mayoritas pada kategori cukup, dan pemenuhan kebutuhan perumahan dan lapangan pekerjaan dan kesempatan berusaha sebagian besar pada kategori rendah.

Makna lahan (tanah) sudah dipahami sebagai sesuatu yang penting, tetapi pengetahuan dan kemampuan untuk mengelola dan memanfaatkan lahan tersebut secara produktif masih sangat rendah. Kemauan dan kemampuan belajar penduduk miskin untuk secara terus-menerus memperbaiki kualitas perilakunya sangat rendah. Masyarakat, khususnya warga miskin belum menyadari pentingnya proses belajar guna memperbaiki kualitas perilakunya agar mereka dapat meningkatkan kualitas kehidupan keluarganya.

\section{Daftar Pustaka}

Sajogyo. 1996. Memahami dan Menanggulangi Kemiskinan di Indonesia. Jakarta: Grasindo.

Sen, A. 1982. Poverty and Famines. Clarendon Press-Oxford.

Sherraden, M. 2006. Aset untuk Orang Miskin. Jakarta: PT. Raja Grafindo Persada. Singarimbun, M., dan Effendi, S. 1985. Metode Penelitian Survai. Jakarta: LP3ES. Susanto, Dj. 2006. "Proses Belajar : Tantangan dalam Penelitian Bidang Pembangunan Pendidikan Masyarakat.” Diknas: Jurnal Teknodik, No. 19/X/TEKNODIK/Desember/ 2006.

Tan, Melly G. 1991. Perubahan Struktur Sosial di Bengkulu. Yogyakarta: UGM Press. Wiradi, G., dan Tjondronegoro, S.M.P. 1984. Dua Abad Penguasaan Tanah, Pola Penguasaan Tanah Pertanian di Jawa dari Masa ke Masa. Jakarta: Gramedia. 